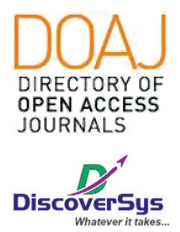

Published by DiscoverSys

\section{Profil onikomikosis pada pasien lanjut usia di Rumah Sakit Umum Pusat Sanglah, Bali, Indonesia: Studi retrospektif}

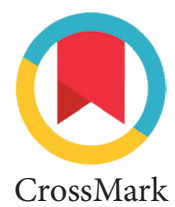

\author{
I Gusti Ayu Agung Dwi Karmila," Made Swastika Adiguna, Luh Made Mas Rusyati
}

\title{
ABSTRACT
}

Background: Fungal infections are one of the most common dermatologic conditions affecting elderly population. Elderly population is susceptible to all of the superficial mycoses such as tinea pedis, candidiasis, and onychomycosis in geriatric populations compared to other age groups.

Objective: To determine the profile of onychomycosis among elderly patients over a period of 1 years (January 2018-August 2019) at Dermatology and Venereology outpatient clinic, Sanglah General Hospital

Methods: Retrospective study was performed at Department of Dermatology and Venereology, Sanglah General Hospital, Denpasar, Bali. The data collected from patient's register data of outpatient clinic. Result: A total of 11 patients were diagnosed with onychomycosis, consist of 5 women and 6 men. From these, 4 (36,3\%) was reported with chronic systemic diseases and 7 (63,6\%) reported with no concomitant diseases. The most common clinical sign were onychodystrophy, hyperkeratotic subungual and dyschromia (6 patients, 54,54\%). Potassium hydroxide examination reveal positive results in all patient. From 5 patients, on culture examination, Candida (2 patients, 40\%), Trichophyton rubrum (2 patients, 40\%), and Trychophyton mentagrophytes (1 patient, 20\%) were found. For therapy, there were 7 patients got combination therapy (fluconazole $150 \mathrm{mg}$ and ciclopirox lacquer 8\%) and 4 patients with single therapy (ciclopirox lacquer 8\%).

Conclusion: Onychomycosis is more common in the elderly or geriatric patients, this occurs because old age can change the body's immune function, including decreased immune response to fight infections against viruses, bacteria, and fungi.

Keywords: onychomycosis, geriatric

Cite This Article: Karmila, I.G.A.A.D., Adiguna, M.S., Rusyati, L.M.M. 2020. Profil onikomikosis pada pasien lanjut usia di Rumah Sakit Umum Pusat Sanglah, Bali, Indonesia: Studi retrospektif. Intisari Sains Medis 11(1): 364-368. D0I: 10.15562/ism.v11i1.653

ABSTRAK

Pendahuluan: Infeksi jamur adalah salah satu kondisi dermatologis paling umum yang mempengaruhi populasi lansia. Populasi lansia rentan terhadap semua mikosis superfisial seperti tinea pedis, kandidiasis, dan onikomikosis pada populasi geriatri dibandingkan dengan kelompok usia lainnya.

Tujuan: Untuk menentukan profil onikomikosis pada pasien usia lanjut selama 1 tahun (Januari 2018 - Agustus 2019) di poliklinik rawat jalan Dermatologi dan Venereologi, Rumah Sakit Umum Pusat Sanglah.

Metode: Studi retrospektif dilakukan di Departemen Dermatologi dan Venereologi, Rumah Sakit Umum Pusat Sanglah, Denpasar, Bali. Data dikumpulkan dari data pendaftaran pasien di klinik rawat jalan.

Hasil: Sebanyak 11 pasien didiagnosis menderita onikomikosis, terdiri dari 5 wanita dan 6 pria. Dari hasil ini, sebanyak 4 orang (36,3\%) dilaporkan dengan penyakit sistemik kronis dan 7 orang $(63,6 \%)$ dilaporkan tanpa penyakit bersamaan. Tanda klinis yang paling umum adalah onikodistrofi, hiperkeratotik subungual dan dischromia $(6$ pasien, 54,54\%). Pemeriksaan kalium hidroksida mengungkapkan hasil positif pada semua pasien. Dari 5 pasien pada hasil pemeriksaan kultur ditemukan adanya infeksi Candida (2 pasien, 40\%), Trichophyton rubrum (2 pasien, 40\%), dan Trychophyton mentagrophytes (1 pasien, 20\%). Untuk penatalaksanaan, terdapat sejumlah 7 orang pasien mendapatkan terapi kombinasi (fluconazol $150 \mathrm{mg}$ dan ciclopirox lacquer 8\%) dan 4 orang pasien dengan terapi tunggal (ciclopirox lacquer 8\%).

Simpulan: Onikomikosis lebih sering terjadi pada pasien usia lanjut atau usia lanjut dimana hal ini terjadi karena usia tua dapat mengubah fungsi kekebalan tubuh, termasuk penurunan respons imun untuk melawan infeksi terhadap virus, bakteri, dan jamur.
Universitas Udayana, Sanglah General Hospital, Bali, Indonesia d.karmila@yahoo.com

Diterima: 29-10-2019

Disetujui: 20-03-2020

Diterbitkan: 01-04-2020
Kata kunci: onikomikosis, geriatri

Cite Pasal Ini: Karmila, I.G.A.A.D., Adiguna, M.S., Rusyati, L.M.M. 2020. Profil onikomikosis pada pasien lanjut usia di Rumah Sakit Umum Pusat Sanglah, Bali, Indonesia: Studi retrospektif. Intisari Sains Medis 11(1): 364-368. D01: 10.15562/ism.v11i1.653 


\section{PENDAHULUAN}

Berdasarkan Peraturan Pemerintah Republik Indonesia Nomor 43 Tahun 2004, disebut lanjut usia adalah seseorang yang telah mencapai usia 60 (enam puluh) tahun ke atas. Populasi usia lanjut di Indonesia semakin meningkat, baik jumlah maupun proporsi, hal ini disebabkan oleh penurunan angka fertilitas kelahiran dan mortalitas (kematian), serta peningkatan angka harapan hidup (life expectancy), yang mengubah struktur penduduk secara keseluruhan. Masalah kesehatan pada mereka yang berusia lanjut, secara kuantitatif dan kualitatif, kompleks dan membutuhkan perhatian khusus. Proses terjadinya penuaan penduduk dipengaruhi oleh beberapa faktor, misalnya: peningkatan gizi, sanitasi, pelayanan kesehatan, hingga kemajuan tingkat pendidikan dan sosial ekonomi yang semakin baik. ${ }^{1}$

Seiring bertambahnya usia, gangguan terkait kulit meningkat. Ada dua jenis penuaan kulit: penuaan intrinsik, yang mencakup perubahan yang disebabkan oleh kondisi penuaan normal dan terjadi pada semua individu, dan penuaan ekstrinsik, disebabkan faktor ekstrinsik seperti paparan sinar ultraviolet (UV), merokok, dan polusi lingkungan. Perubahan histologis juga terjadi karena penuaan dan fotoaging. Pertumbuhan kuku menjadi lambat, dengan penipisan lempeng kuku. ${ }^{2}$

Onikomikosis adalah penyakit kuku yang paling umum, 50-60\% dari onikomikosis didahului dengan kuku yang rusak. Prevalensi onikomikosis meningkat seiring bertambahnya usia mencapai $20 \%$ pada pasien berusia $>60$ tahun. Dalam sebuah penelitian terhadap 15.000 onikomikosis di Kanada, 90\% disebabkan oleh dermatofita (Trichophyton rubrum, T. mentagrophytes), $8 \%$ disebabkan oleh non dermatofita dari kapang (Aspergillus, Fusarium) dan $2 \%$ kasus onychoCandida. ${ }^{3}$

Penelitian ini bertujuan untuk mengetahui prevalensi dan profil onikomikosis pada pasien geriatri yang berusia $>60$ tahun di Poliklinik Kulit dan Kelamin subdivisi mikologi RSUP Sanglah Denpasar Bali periode Januari 2018 hingga Agustus 2019.

\section{METODE}

Penelitian dilakukan secara retrospektif dengan mengambil data dari catatan medis pasien baru berusia $>60$ tahun yang datang ke Poliklinik Kulit dan Kelamin subdivisi mikologi RSUP Sanglah Denpasar Bali dari Januari 2018 hingga Agustus 2019. Diagnosis ditegakkan dari anamnesis dan pemeriksaan fisik serta pemeriksaan mikroskopis dengan Kalium Hidroksida (KOH). Data yang dianalisis meliputi jenis kelamin, usia, hasil evaluasi mikroskopis dengan $\mathrm{KOH}$ dan penatalaksanaan yang diberikan.

\section{HASIL}

Dikumpulkan data selama 1 tahun dari Januari 2018 - Agustus 2019 di Poli Kulit dan Kelamin divisi mikologi RSUP Sanglah, Denpasar ditemukan 11 pasien geriatri yang didiagnosis dengan onikomikosis yang dapat dilihat pada tabel 1 sebagai berikut:

Dari tabel tersebut terdapat $5(45,4 \%)$ pasien onikomikosis wanita dan $6(54,6 \%)$ pasien onikomikosis laki-laki. Sebayak $4(36,3 \%)$ orang yang disertai penyakit sistemik dan $7(63,7 \%)$ orang tidak terdapat disertai penyakit sistemik. Manifestasi klinis onikomikosis yang tersering adalah onikodistrofi, hyperkeratosis subungual dan diskromia ditemukan pada $6(54,5 \%)$ orang pasien yang dapat dilihat pada gambar $1 \mathrm{a}$ dan $1 \mathrm{~b}$.

Dilakukan kultur untuk menetukan spesies jamur, terdapat spesies jamur Candida pada 2 (40\%) pasien, 2 (40\%) pasien dengan T. Rubrum dan 1 (20\%) pasien dengan T. Menthagrophytes yang dapat dilihat pada gambar $2 \mathrm{a}$ dan $2 \mathrm{~b}$.

Diberikan terapi kombinasi sistemik dengan Fluonazole $150 \mathrm{mg}$ dan topikal dengan siklopiroks nail lacquer 8\% kepada $7(63,6 \%)$ pasien dan

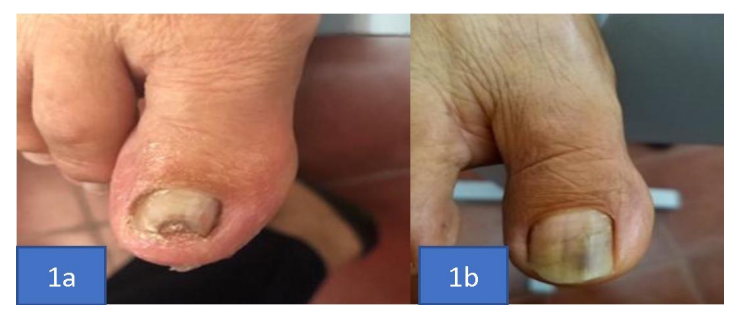

Gambar 1a dan b Gambaran manifestasi klinis onikomikosis tersering: onikoidstrofi, hiperkeratosis subungual dan diskromia

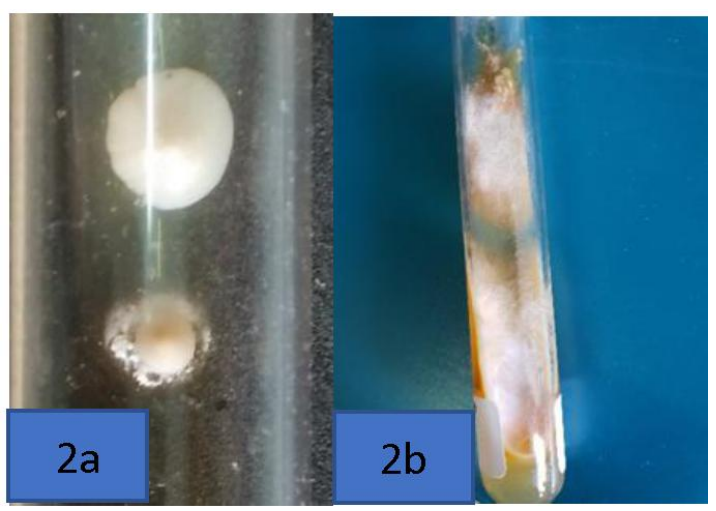

Gambar 2 a) Gambaran kultur jamur spesies jamur candida; b) Gambaran kultur jamur spesies T. Rubrum 
Tabel 1 Karakteristik onikomikosis pada pasien geriatri poliklinik kulit dan kelamin di divisi mikologi RSUP Sanglah, Denpasar, Bali

\begin{tabular}{|c|c|c|c|c|c|c|c|}
\hline No & Umur & $\begin{array}{c}\text { Jenis } \\
\text { kelamin }\end{array}$ & Klinis & KOH & Kultur & Terapi & $\begin{array}{l}\text { Penyakit } \\
\text { penyerta }\end{array}$ \\
\hline 1 & 60 & $\mathrm{~L}$ & $\begin{array}{l}\text { onikodistrofi, hiperkeratosis } \\
\text { subungual }\end{array}$ & + & & fluconazole $150 \mathrm{mg}$ & \\
\hline 2 & 68 & $\mathrm{~L}$ & $\begin{array}{l}\text { onikodistrofi, hiperketosis subungual, } \\
\text { diskromia }\end{array}$ & + & & siklopiroks $8 \%$ & $\mathrm{CKD}^{*}$ \\
\hline 3 & 67 & $\mathrm{~L}$ & $\begin{array}{l}\text { onikodistrofi, hiperketosis subungual, } \\
\text { diskromia }\end{array}$ & + & candida & fluconazol 300mg & \\
\hline 4 & 68 & $\mathrm{~L}$ & $\begin{array}{l}\text { onikodistrofi, hiperketosis subungual, } \\
\text { diskromia }\end{array}$ & + & & siklopiroks $8 \%$ & \\
\hline 5 & 64 & $\mathrm{P}$ & $\begin{array}{l}\text { onikodistrofi, hiperkeratosis } \\
\text { subungual }\end{array}$ & + & t. rubrum & $\begin{array}{l}\text { fluconazole } 150 \mathrm{mg} \text {, } \\
\text { siklopiroks } 8 \%\end{array}$ & $\begin{array}{l}\text { Diabetes } \\
\text { mellitus }\end{array}$ \\
\hline 6 & 62 & $\mathrm{~L}$ & $\begin{array}{l}\text { onikodistrofi, hiperkeratosis } \\
\text { subungual, diskromia }\end{array}$ & + & & $\begin{array}{l}\text { fluconazol 150mg, } \\
\text { siklopiroks } 8 \%\end{array}$ & \\
\hline 7 & 68 & $\mathrm{P}$ & $\begin{array}{l}\text { onikodistrofi, hiperkeratosis } \\
\text { subungual }\end{array}$ & + & t. rubrum & $\begin{array}{l}\text { fluconazole } 150 \mathrm{mg} \text {, } \\
\text { siklopiroks } 8 \%\end{array}$ & $\begin{array}{l}\text { Gagal jantung } \\
\text { kongestif }\end{array}$ \\
\hline 8 & 66 & $\mathrm{~L}$ & $\begin{array}{l}\text { onikodistrofi, hiperkeratosis } \\
\text { subungual }\end{array}$ & + & candida & $\begin{array}{l}\text { fluconazole } 150 \mathrm{mg} \text {, } \\
\text { siklopiroks } 8 \%\end{array}$ & \\
\hline 9 & 62 & $\mathrm{~L}$ & $\begin{array}{l}\text { onikodistrofi, hiperkeratosis } \\
\text { subungual, diskromia }\end{array}$ & + & & siklopiroks $8 \%$ & \\
\hline 10 & 61 & $\mathrm{P}$ & $\begin{array}{l}\text { onikodistrofi, hiperkeratosis } \\
\text { subungual, diskromia }\end{array}$ & + & t. menthagrophytes & $\begin{array}{l}\text { fluconazole } 150 \mathrm{mg} \text {, } \\
\text { siklopiroks } 8 \%\end{array}$ & Hipertensi \\
\hline 11 & 60 & $\mathrm{P}$ & $\begin{array}{l}\text { onikodistrofi, hiperkeratosis } \\
\text { subungual, diskromia }\end{array}$ & + & & siklopiroks $8 \%$ & \\
\hline
\end{tabular}

diberikan hanya terapi topikal dengan siklopiroks nail lacquer $8 \%$ kepada $4 \quad(36,4 \%)$ pasien. Didapatkan hasil dengan kombinasi terapi lebih baik dibandingkan dengan monoterapi.

\section{DISKUSI}

Di negara berkembang, masalah sosial ekonomi dan masalah kesehatan penyakit lain masih sebagai prioritas utama, sehingga kesadaran akan onikomikosis oleh dokter dan masyarakat umum masih sangat rendah. Onikomikosis merupakan salah satu dermatomikosis yang sering terjadi pada pasien geriatri, selain tinea pedis, tinea kruris dan kandidiasis. Onikomikosis terjadi sekitar 5\% dari populasi di seluruh dunia dan sekitar 30\% merupakan dermatomikosis. ${ }^{4}$ Penelitian multisenter di Amerika Utara, dari 15.000 pasien yang datang ke pelayanan kesehatan, sebanyak 2505orang (16,7\%) dengan kelainan di kuku dan 1199 orang $(8,0 \%)$ didiagnosis onikomikosis. ${ }^{5}$ Di Indonesia, prevalensi onikomikosis menunjukkan angka yang lebih rendah, yaitu 3,5-4,7\% diantara kasus dermatomikosis. ${ }^{6}$ Pada penelitian ini didapatkan 11 pasien onikomikosis dengan proporsi lebih banyak pada laki-laki yaitu 54,6\% dibandingkan dengan proporsi onikomikosis pada perempuan $(45,4 \%)$.
Penyebab onikomikosis yang banyak dilaporkan di Indonesia adalah Candida spp., T.rubrum dan T.mentagrophytes. Identifikasi spesies fungi sebagai penyebab onikomikosis pada pasien usia lnjut di Brazil didapatkan T.rubrum sebagai penyebab terbanyak yaitu $51,40 \%$ dari 35 orang yang diperiksa. ${ }^{7}$ Dari data kami di RS Sanglah, hanya 5 spesimen pasien yang menunjukkan pertumbuhan elemen jamur pada hasil kulturnya, dengan hasil 2 spesimen menunjukkan spesies candida dan 2 spesimen T.rubrum, dan hanya 1 spesiemen pasien menunjukkan T. mentagrophytes.

Banyak faktor risiko yang berperan dalam onikomikosis, antara lain usia, jenis kelamin, genetik, faktor lingkungan yaitu iklim panas, lembab, sering menggunakan sepatu tertutup, berjalan tanpa menggunakan alas kaki, trauma berulang pada kuku, hiperhidrosis, dan penggunaan pemotong kuku secara Bersama, aktivitas olahraga, imunodefisiensi, diabetes mellitus dan riwayat infeksi dermatofita pada lokasi lain. ${ }^{6}$ Pada kelompok geriatri dengan usia lebih dari 60 tahun mulai rentan terhadap masalah yang bervariasi di mulai dari masalah kesehatan maupun biopsikososial. Pada usia lebih dari 60 tahun telah mengalami perubahan sistem imunitas tubuh, respon imun menurun sehingga memiliki risiko lebih besar 
terhadap infeksi ataupun penyakit kronis. Faktor risiko terjadinya onikomikosis pada usia lanjut adalah adanya penyakit sistemik seperti diabetes melitus dan riwayat trauma pada kuku. ${ }^{8}$ Dari 11 pasien usia lanjut yang didiagnosis onikomikosis, $4(36,3 \%)$ orang yang disertai penyakit sistemik, yaitu diabetes mellitus, gagal jantung, hipertensi dan CKD.

Manifestasi klinis onikomikosis dipengaruhi oleh pola invasi jamur terhadap kuku, dan dikenal 5 klasifikasi onikomikosis sebagai berikut: onikomikosis subungual distal dan lateral, onikomikosis subungual proksimal, onikomikosis superfisial, onikomikosis endoniks, dan onikomikosis total distrofik. Semua pasien onikomikosis usia lanjut pada penelitian ini dengan manifestasi klinis hiperkeratosis subungual dan semua pasien dengan manifestasi klinis onikomikosis subungual distal dan lateral. Penegakan diagnosis onikomikosis sulit hanya dengan anamnesis dan gambaran klinis saja, maka diperlukan pemeriksaan penunjang untuk menegakkan diagnosis dan mengetahui penyebab onikomikosis. Pemeriksaan penunjang yang dapat dilakukan yaitu pemeriksaan mikroskopik langsung dan pemeriksaan dengan biakan atau kultur untuk identifikasi jamur penyebab, pemeriksaan dengan dermoskopi serta histopatologis jika perlu. ${ }^{6}$ Pemeriksaan mikroskopik langsung diperlukan bahan dari kerokan kuku pada sediaan $\mathrm{KOH}$ 20-30\% dalam air atau dalam dimetilsulfoksida (DMSO) 36-40\% untuk mempermudah lisis keratin sehingga dapat melihat adanya hifa, pseudohifa, spora, dan blastospora. Semua kasus onkomikosis pada pasien geriatri penelitian ini didukung dengan pemeriksaan mikroskopik langsung dari kerokan kuku pada sediaan $\mathrm{KOH} \mathrm{20-30 \%} \mathrm{dan} \mathrm{semua} \mathrm{kasus}$ ditemukan elemen jamur. Pemeriksaan biakan kultur dengan media Agar Sabouraud hanya dikerjakan pada 5 pasien onikomikosis dengan pertumbuhan spesies Candida pada $2(40 \%)$ pasien, 2 (40\%) pasien dengan T. Rubrum dan 1 (20\%) pasien dengan T. Menthagrophytes.

Terapi onikomikosis bertujuan untuk mengeradikasi jamur dari kuku yang dibuktikan dengan sediaan mikroskopis maupun biakan dan mencapai kesembuhan secara klinis. Kelainan ini memang tidak mengancam jiwa dan mungkin saja bahkan tidak mengganggu aktifitas. Tidak semua pasien mau diberikan terapi onikomikosis akan tetapi kuku jari tangan ataupun kaki yang telah terinfeksi jamur dapat sebagai reservoir jamur dan bias menyebarkan infeksi jamur ke bagian tubuh yang lain. ${ }^{9}$ Sebelum pemilihan terapi onikomikosis pada usia lanjut, perlu dipertimbangkan adanya faktor-faktor yang berkontribusi pada respon yang buruk terhadap terapi ataupun terjadinya rekurensi. Karakteristik kuku pada pasien geriatri yaitu nail plate yang abnormal, pertumbuhan kuku yang lambat, keterlibatan matriks kuku ataupun kuku yang terkena $>75 \%$. Adanya penyakit sistemik seperti diabetes mellitus, penyakit pembuluh darah perifer dan kondisi imunosupresi perlu dipertimbangkan sebelum pengobatan..$^{9,10}$ Modalitas terapi yang telah dikenal meliputi obat antijamur sistemik yaitu terbinafin, itrakonazol, flukonazol, obat antijamur topikal antara lain amorolfin dan siklopiroks. Terapi bedah seperti avulsi kuku, terapi alternatif lainnya yaitu laser, fotodinamik, iontoforesis dan ultrasound, serta kombinasi antara modalitas terapi tersebut. ${ }^{6,9}$ Dari penelitian ini pemberian terapi kombinasi sistemik yaitu Fluonazole $150 \mathrm{mg}$ dan topikal dengan siklopiroks nail lacquer 8\% kepada 7 (63,6\%) pasien dan pemberian monoterapi yaitu siklopiroks nail lacquer $8 \%$ kepada $4(36,4 \%)$ pasien. Kombinasi terapimemberikan prognosis lebih baik dibandingkan dengan monoterapi.

\section{SIMPULAN}

Onikomikosis lebih sering terjadi pada usia lanjut atau pasien geriatri, hal ini terjadi karena pada usia lanjut dapat terjadi perubahan fungsi imunitas tubuh termasuk penurunan respon imunitas untuk melawan infeksi terhadap virus, bakteri, dan jamur. Sebelas kasus onikomikosis pada lansia di poliklinik kulit dan kelamin RS Sanglah, beberapa pasien memiliki komorbiditas. Terapi kombinasi memberikan hasil yang lebih baik daripada terapi tunggal dan memerlukan perhatian khusus dalam pertimbangan pemberian terapi. Tindakan pencegahan dan edukasi kesehatan tentang infeksi jamur sangat perlukan sehingga dapat mengurangi risiko menderita onikomikosis ataupun dermatomikosis yang lain.

\section{KONFLIK KEPENTINGAN}

Penulis menyatakan tidak terdapat konflik kepentingan terkait publikasi dari penelitian ini.

\section{PENDANAAN}

Penelitian ini tidak mendapatkan bantuan dana hibah dari pemerintah maupun sektor swasta lainnya.

\section{ETIKA DALAM PENELITIAN}

Penelitian ini telah mendapatkan persetujuan dari Komite Etik Fakultas Kedokteran Universitas Udayana/RSUP Sanglah Denpasar. 


\section{DAFTAR PUSTAKA}

1. Anonim. Analisis Lansia Indonesia. Pusat Data dan Informasi Kementrian Kesehatan RI. 2017.

2. Robert A. Geriatric Dermatology. Dermatologic Therapy. 2003. Vol 16: 260 - 268.

3. Aditya K, Gupta, Hem C, Jain, Charles W, Lynde, et al. Prevalence and Epidemiology of Onychomycosis in Patients Visiting Physicians' Offices: A Multicenter Canadian Survey of 15,00 Patients. American Academy of Dermatology. 2000. 43: 244-248.

4. Kaur R, Kashyap B, Bhalla P. Onychomycosisepidemiology, diagnosis and management. Indian J Med Microbiol. 2008;26:108-16.

5. Gupta AK, Jain HC, MD, Lynde CW, MacDonald P, Cooper EA, Summerbell RC. Prevalence and epidemiology of onychomycosis in patients visiting physicians' offices: A multicenter Canadian survey of 15,000 patients. J Am Acad Dermatol. 2000;43:244-8.

6. Bramono K, Suyoso S, Indriatni W, Ramali LM, WIdaty S, Ervianti E. Dermatomikosis Superfisialis Pedoman untuk Dokter dan Mahasiswa Kedokteran. Edisi 2. Jakarta: Badan Penerbit FKUI. 2013. p.86-99.
7. Vasconcellos C, Pereira CQM, Souza MC, Pelegrini A, Freitas RS, Takahashi JP. Identification of fungi species in the onychomycosis of institutionalized elderly. An Bras Dermatol. 2013;88(3):377-80.

8. Gupta AK, Daigle D, Foley KA. The prevalence of culture-confirmed toenail onychomycosis in at-risk patient populations. JEADV. 2015;29:p1039-1044.

9. Loo DS. Onychomycosis in the elderly: drug treatment options. Drugs Aging 2007; 24: 293-302.

10. Gupta AK, Daniel CR III. Factors that may affect the response of onychomycosis to oral antifungal therapy. Australas J Dermatol. 1998;39(4):222-4.

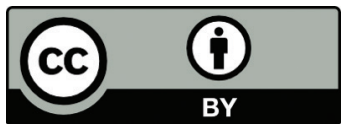

This work is licensed under a Creative Commons Attribution 